\title{
The Relevance among Preservice English Teachers' Preparation Courses, Their Views about Teaching and Their Real Teaching Behaviors (A Case Study)
}

\author{
Hosam ElDeen Ahmed El-Sawy \\ Damanhour University, Egypt; \\ Jouf University, KSA
}

\begin{abstract}
This study aims at investigating the relevance among three factors: preservice English teachers' preparation courses, their views about teaching and their real teaching behaviors. This is a case study focusing on three preservice teachers of English in Egypt. Data was collected through three tools: an observation sheet, a semi-structured interview and a focus group. Results of the study revealed that there is a gap between what preservice English teachers learn in their preparation courses, their views about effective teaching and their real behaviors in class. The reasons which the participants gave for not applying what they have learned theoretically include: insufficient preservice training, students' low level, insufficient class time, students' resistance of changing the way they are used to learn, insufficiency of equipment in schools, students' preference of using the native language in learning, and in one case the teacher herself preferred the traditional grammar translation method. The study recommends early coordination between teacher preparation institutions and schools. The study recommends the incorporation of senior teachers in teacher preparation programs to try to breach the theory-practice gap. The study also recommends that teacher educators should analyze the given causes of the theory-practice gap and develop the English teachers' preparation courses in accordance.
\end{abstract}

Index Terms - preservice English teachers, preparation courses, teaching behaviors, gap

\section{INTRODUCTION}

The teacher is the keystone in the educational system. Thus, teacher preparation programs are very important for the development of any educational system. The teaching of English in Egypt faces many problems. The most serious problem is that students in pre-college stages study English from Kindergarten until they finish high school; though, They achieve very high marks in national exams, their real level of English is very low. They do not master the four language skills in a satisfactory way. This is due to many reasons but the most important reason from my point of view is the teacher.

Teachers of English in Egypt are prepared at colleges of education and are provided with different theories and methods of teaching English as a foreign language. However, when they start their career a great difference is noticed between what they have learnt at college and what they really practice in schools. This gap between theory (what they have learnt at college) and practice (how they teach in schools|) starts early in their teaching practice courses. This poses the question of the avail and worthiness of teacher education in Egypt and its relation to teaching practices.

The gap between the theory and practice in teaching English as a foreign language is an important topic for investigation. This topic of theory practice gap has not been investigated deeply in Egypt. It is important to investigate the English teacher preparation programs in Egypt and investigating the gap that occurs between theory and practice. This could help find out the roots of the problem and could help find possible solutions.

Preservice English teachers in Egypt often complain about the lack of relevance of the theoretical courses in their preparation programs and the real teaching in classes. The big challenge for teacher educators is creating relevant links between practice and theory in English teachers' preparation programs.

\section{REVIEW OF LITERATURE}

Examining the literature in the area of the gap between theory and practice in English teachers' preparation and their real teaching behaviors reveals the focus on certain issues. These issues include: explaining the gap showing its significance; teachers views about this problem; and the suggested solutions.

Explaining the gap and its significance:

Some main issues in this respect is the collaboration between teacher preparation institutions and schools. Another issue is the linkage between what is taught in teacher preparation and practicing it directly when learned. Another main 
issue is the various reasons of the gap between theory and practice in teaching English. These three issues appears in many studies.

Many teacher preparation programs do not carefully address the classroom contexts in which teachers work (Buthelezi, 2004). In this regard, Samuel (1998) asserted that preservice teacher education, should form a collaboration between institutions of teacher training and schools. He argued that both teacher educators and teachers should constantly check the existing teaching practices and theories to find out the gap between practices and theories so that they can work collaboratively to breach this gap through new techniques. Similarly, Mukeredzi and Mandrona (2013) examimed the experiences of 14 Bachelor of Education students who participated in a four-week teaching practice in a school in South Africa. The researchers collected data from the preservice teachers' reflective journals and conducted collaborative reflection sessions. Results of their study revealed that preservice teachers had positive experiences concerning collaborative reflection sessions and classroom practices. However, the preservice teachers had negative experiences with supervisors and the school system. The researchers argued that the challenges which preservice teachers experience may constitute their ability to obtain great benefit from their preservice training.

Ping (2015) investigated preservice teachers' perception of their preparation. The study aimed at checking the 2010, 2011, 2012, 2013 cohorts studying for a BA in TEFL and examining the effectiveness of four- -year pre-service English preparation program in Chinese universities, and what needs to be modified or sustained from the perspective of preservice teachers. Data was collected through the use of questionnaires and semi-structured interviews. Three hundred participants completed the questionnaires and two hundred of them were randomly selected for the semi-structured interviews. One issue of the study was related to the gap between theory and practice. The study revealed that preservice teachers only had tests to demonstrate what they had learned instead of applying the theories they learn in real teaching practice. Consequently, most of the BA preservice TEFL teachers had forgotten the theoretical knowledge they had learned when asked about it in the final exam. They researcher asserted that only when abstract theory was linked with classroom practice could learners remember and apply it.

Kirkgoz (2008) conducted a case study focusing on the impact of teacher training on their implementation of the Communicative Oriented Curriculum in teaching English to young students in Turkish formal schools. The researcher collected data through various tools including classroom observations, interviews and lesson transcripts. Thirty-two teachers participated in this case study. Results of the study revealed that teachers' prior training had an effect on the extent of their implementation of the communicative oriented curriculum. The study recommends providing teachers with ongoing opportunities for training and development, especially during the first few years of applying a new curriculum. Kirkgoz (2008) gave some reasons for the gap between practice and theory. The main reason was that the new curriculum aims and objectives were borrowed from western contexts with little attention to the specialty of Turkish settings. The researcher adds that other reasons explaining the theory-practice gap are teachers' perceptions, their prior training, the insufficient guidance, the effect of textbooks, large classes and lack of suitable needed resources. The researcher reported that studies exploring these reasons are reported by researchers from different contexts such as Kırkgo“z, 2006, 2007 in Turky; Hu, 2002 in China; Carless, 1998, 2001, 2003 in Hong Kong; Nunan, 2003 in the AsiaPacific region; and Li, 1998 in South Korean.

Özdemir et al (2015) investigated how much knowledge preservice teachers can apply in their teaching practice. The researcher collected data through an open-ended interview. The participants of the study were forty-two senior year students from various departments at the faculty of education at a university in Turkey. The study revealed that, the themes participants could turn into practice the most successfully were "communication with the students" and "classroom management". Whereas, the least themes successfully transformed into practice were "knowledge of subject area", and "students' development assessment". The reason provided for the gap between theory and practice was the lack of sufficient number of practical courses in the teacher preparation program investigated.

Cheng et al (2010) examined the inconsistencies between student teachers' best teaching strategies and their most commonly employed ones. The researchers collected data through an interview. Findings of the study revealed three main reasons of the inconsistencies between theory and practice. These three reasons were the preservice teachers' perceptions of teaching, their pre-training experience, and the school context in which they do their practice.

Hatasa (2013) focused on exploring the reasons the theory-practice gap occurs and persists. The researcher stated that the social perceptions of researchers and teachers are different and this is the main reason for the gap between theory and practice. Moreover, the researcher emphasizes that the profession of a researcher is greatly different form the profession of a teacher. Consequently, both teachers and researcher have different ways in interpreting the value of different teaching practices.

Tudor (2003), claims that the teacher's reality is thus an ecological one which is shaped by the attitudes and expectations of students, parents, school administrators, material writers and many others including, of course, each teacher as an individual in his or her own right. The factors contributing to the gap between teachers' beliefs and actual teaching practices may be rooted in teachers' inability to articulate their beliefs, or in student variables (e.g. student proficiency level and learning attitudes or motivation) in educational contexts (e.g. a mandated syllabus, insufficient instruction time, large classes, grammar-based examinations). They may also result from institutional culture e.g. institutional requirements, heavy teaching load, negative collegiality, or from teachers' wish to promote a particular image of themselves (cited in Fayyaz and Omar 2014 ). 
As seen in this section, a lot of studies discussed the theory-practice gap focusing on its causes. However, none of these studies focused on the comparison among the three major factors involved in the problem. These factors can be clarified by comparing what preservice EFL teachers learn, their own views about effective teaching techniques and their real teaching behaviors. This is the purpose of the present study.

\section{Teachers' views about the theory-practice gap:}

Few studies tried to investigate what preservice teachers think about the relationship between theory and practice. Peercy (2012) studied preservice teachers' perceptions of their preparation programs and their awareness of the practical and theoretical issues involved in these programs. The study also investigated the image those preservice teachers form for themselves as teachers. The study found out that the issue of theory-practice relationship is clear in ESL perceptions of their preparation programs. Moreover, exploring theory and practice has continuing importance because teachers' understandings of the relationship between theory and practice differ in ways that are related to the image preservice teachers form for themselves as teachers. That is why there is a strong need for more research that investigates what aspects of preparation programs are perceived as valuable or not valuable and what are the factors affecting this perception. The researcher added that it is necessary to encourage preservice ESL teachers to discuss their assumptions about the language, and help them discover the practical implications of these assumptions in teaching English. The researcher also pinpointed the importance of guiding preservice ESL teachers to analyze the theories related to the nature of language and think of ways they can apply these theories in teaching English as a second language.

Fayyaz and Omar (2014) discussed the relationship between beliefs and practices as well as factors shaping the beliefs of EFL/ESL teachers. The researchers found out that teachers have both interpersonal and intrapersonal beliefs. These beliefs are formed from theories preservice teachers study as well as their own experiences in life. The researchers added that these beliefs are not rigid as they are modified during actual practice in school settings. The researchers discovered that the influence of taught theories in real practice is little. This refers to the gap of theory and practice in language teaching. What preservice teachers learn in their preparation programs has little influence on their actual teaching of the language.

Safari and Rashidi (2015) studied the application of post-transmission theories by Iranian English language teachers and the challenges they face when applying these theories. The participants in the study were ten experienced teachers of English and three teacher educators. The researchers gathered data through three instruments: reflective narratives, collaborative dialogues and interviews. The researchers found out that participants thought that it is important to modify the Iranian teacher preparation programs using alternative approaches and methods to achieve a better result. However, they clarified that this process of development of teacher preparation programs should be carefully thought of by all personal involved.

As seen in this section, very few studies covered the issue of students' beliefs and views about teaching English. Also, most of these studies focused on general beliefs and views about teaching the language. That is why the present study seeks to investigate preservice English teachers' views about teaching language in relation to their training and their real teaching behaviors.

\section{Suggested Solutions to the problem:}

The suggested solutions to the problem of theory-practice gap include taking into consideration students' learning experiences; mentoring systems between teachers and researchers; bringing practicing teachers into higher education context; online collaboration between preservice teachers; and incorporating more practical courses in English teacher preparation programs. These solutions were presented by the following studies.

Edge and Mann (2013) found out that their initial teacher preparation program might have hindered students' ability to close the gap between theory and practice because it never took the student teachers' own experiences as a learner as a starting point; they did not explicitly guide student teachers in exploring their own initial beliefs about language learning and teaching. They concluded that if this is done, they are going to have a positive effect on both students' willingness to entertain new theoretical notions and their ability to integrate new ideas with existing ideas.

D'Souza (2014) examined the benefits of an unintended mentoring relationship between researchers and beginning teachers during a longitudinal, qualitative study. The study highlights the opportunity for teacher preparation to serve as a bridge to close the gap in learning between the relatively theoretical world of teacher preparation and practical world of classroom teaching. The study analyzed extensive qualitative data relating to two beginning teachers over a five-year period. This study provided support for developing communities of practice to bridge the gap of support between teacher preparation and the teaching profession. The study recommends creating a support network between two individuals with an established, trusting relationship and comparable theoretical groundings. Finally, the relationship must be built around non-evaluative, questioning strategies that encourage teacher inquiry. The established trust and bridge of ideas between a researcher and a participant completing preparation at the same university are key factors in successful support (D’Souza, 2014).

Cope and Stephen (2001) discussed the challenges in the field of teacher preparation programs in two settings, namely schools and higher education institutions. The researchers clarified that the incorporation of practicing teachers in teacher preparation programs has many merits. These merits include the presentation of situated and practical knowledge of teaching to preservice teachers thus providing more quality professional input. The researchers also indicated that the relationship between theory and practice aspects of the preparation programs are questionable. It is 
concluded that involvement of practicing teachers in teacher preparation programs may act as a foundation for developing effective teacher preparation programs and could contribute to the professional development of teachers as well as teacher educators.

Dooly and Sadler (2013) investigated the effect of online collaboration in the field of teacher education programs. The study lasted for two years during which two groups of preservice teachers from Spain and the United States worked collaboratively online with the purpose of achieving better understanding and application of the communicative language teaching approach. The two groups gave each other peer feedback on different learning and teaching activities. The researchers used different tools such as Moodle, emails, Skype, wikis, and podcasting. The researchers analyzed data gathered during the online collaboration between the two groups. Results of the study revealed that the group online collaboration helped teacher development because it created opportunities, which are not available in more traditional teacher preparation programs. The study also revealed that the online collaboration enabled preservice teachers to create strong connections between theoretical aspects and their actual practice inside classrooms.

Kareva (2013) states that one of the biggest challenges that face teacher education in Europe seems to be the gap between theory and practice. The researcher states that the main reason for this gap is the lack of practical work. The researcher suggests that the solution could be to incorporate CELTA (Certificate in Teaching English to Speakers of Other Languages) or elements of it into teacher preparation programs or modify the courses in these programs to be more similar to CELTA activities. By this, the teacher preparation programs can become more practical. Consequently, the gap between theory and practice will be diminished.

To sum up, research concerning the theory-practice gap in teaching English has focused on the reasons of the gap, teachers' perceptions and some solutions to the problem. It is clear that this area needs more research to clarify the factors involved in the problem trying to figure it out reaching the roots and complications that creates it. This could lead to breaching this theory-practice gap and consequently improve the quality of teaching English as a foreign or a second language.

\section{RESEARCH QUESTIONS}

1. How are preservice English teachers prepared in Egypt?

2. What are preservice English teachers' views about effective teaching?

3. What are preservice English teachers' real teaching behaviors in classes?

4. How much is the gap among what preservice English teachers learn in their preparation courses; what they view as effective teaching and what they really do in class?

\section{METHOD}

\section{Participants:}

Three preservice teachers of English from Damanhour, Egypt participated in this project.

\section{Instruments:}

\section{1- Observation sheet of preservice English teachers' teaching behaviors:}

An observation sheet was designed to help record preservice English teachers' real teaching behaviors (appendix 1). The observation sheet focused on the following aspects:

Teachers' techniques in teaching new vocab.

Teachers' techniques in developing the four language skills

Teachers' use of teaching aids

Teachers' use of native language

Levels of students' involvement

Other aspects

\section{2- Interview}

An interview was conducted with the three preservice English teachers. It was a semi- structured interview with a list of flexible questions allowing for further viewpoints from interviewees. The interview questions focused on preservice English teachers' views about effective techniques for the observed aspects: vocabulary presentation, skills development, use of teaching aids, use of native language and students' involvement (Appendix 2).

\section{3- Focus group}

The focus group consisted of the three preservice English teachers and focused on one question which is why did not they apply what they have learnt in preparation courses in their real teaching?

\section{FINDINGS AND DiSCUSSION}

\section{A. Question 1: How Are Preservice English Teachers Prepared in Egypt?}

The researcher studied the English teacher preparation program at the faculty of education, Damanhour University, Egypt as a representative sample of English teachers' preparation programs in Egypt. All colleges of education in Egypt 
follow almost the same study plan with minor differences. Following are the main features and components of this program.

Teacher of English preparation program in Egypt:

Students at English department at colleges of education in Egypt have a combined study. That is to say, they are prepared academically and professionally simultaneously. The study in the program takes four complete years two semesters each. Academically their skills of English are developed through various courses in English literature and English linguistics together with courses for the development of their English language skills (reading, writing, conversation)

Professionally, they study a variety of courses. They study four courses for their direct preparation as teachers of English: TEFL 1, TEFL2, teaching practice 1 and teaching practice 2. Also, they study general courses for teacher preparation including courses of educational psychology, educational foundations and educational administration.

\section{TEFL1}

This course is in the third year of the program, the same academic year they start their teaching practice 1.

The course focuses on practical skills needed inside classrooms to help preservice teachers teach effectively when they go to schools. The main topics of the course are: general terms related to TEFL; lesson planning; vocabulary presentation; grammar presentation; skills development (listening, speaking, reading and writing); and approaches of TEFL. The only theoretical topic is the last one. The main emphasis of the course is on how to plan and apply lessons of English especially how to develop the four language skills.

The course is taught through a lecture given by a PhD member specialized in TEFL and accompanied with practical lessons for each topic given by a teaching assistant or an assistant lecturer specialized in TEFL.

\section{TEFL 2}

The course is in the fourth year of the program, the last year of teachers of English preparation program. Students at this year continue their teaching practice with teaching practice 2.

The course focuses more on current trends in TEFL. The main topics of the course are: approaches of foreign language syllabus design; communicative language teaching; task-based language instruction; using games in language classes; motivation in language learning; skills development revisited.

The course is taught through a lecture given by a PhD member specialized in TEFL and accompanied with practical lessons for each topic given by a teaching assistant or an assistant lecturer specialized in TEFL.

\section{Teaching practice 1 and Teaching practice 2}

Those two courses are not courses taught in campus. They are completely carried out at public schools.

These courses are nearly identical in the procedures they follow except for the level of the school preservice teachers go to. In teaching practice 1 student teachers go to middle schools whereas in teaching practice 2 they go to high schools.

The procedures followed in teaching practice courses are:

- Preservice teachers are divided in groups of 7 or so.

- Every group is assigned to a public school to spend one day a week for a complete academic year.

- Three members help students and evaluate them in these courses (the school principle who is responsible for the administrative aspects of preservice teachers; the educational supervisor, who is responsible for the technical aspects of preservice teachers' training; and the academic supervisor who is a $\mathrm{PhD}$ holder who visits preservice teachers occasionally and supervises their practice)

- Preservice teachers spend about three weeks observing in-service teachers and fill in observation sheets that are prepared for this purpose. After each observation, they meet with the professional supervisors and discuss the class they have observed. This observation and discussion are done in groups.

- Then preservice teachers start teaching one class every week. They prepare a lesson plan beforehand. While teaching two or more of their colleagues observe and fill observation sheets. The educational as well as the academic supervisors observe these classes according to a set schedule. After each class, the whole group meets for discussion.

- At the end of the academic year, preservice teachers spend a complete week at schools acting as full-time teachers. They have a full-time schedule in which they teach more than one class daily. They have visits from the educational and academic supervisors during this week as well as discussion sessions about their performance.

\section{Other courses:}

Students study other courses for their general preparation as teachers. These courses are taught to all students at the faculty of education and not exclusive to the students of English department. These courses include: curriculum; educational technology; methods of teaching for special education; general teaching skills; educational psychology; statistics; measurement; instructional psychology; fundamentals of education; comparative education; education and the problems of society; mental health and psychological counseling; using computers in teaching; and the teacher and the profession of teaching.

\section{B. Questions from Two to Four}

\section{What are preservice English teachers' views about effective teaching?}

2. What are preservice English teachers' real teaching behaviors in classes? 
3. How much is the gap among what preservice English teachers learn in their preparation courses; what they view as effective teaching and what they really do in class?

These three questions of the study are dealt with collectively. That is to say, all data gathered from observation, interviews and the focus group are presented together related to each preservice teacher and discussed.

Preservice English teacher 1:

Vocab. presentation

- Teacher asks "What is the meaning of ....?" students provide Arabic meaning of the word and if they don't know teacher provides the Arabic translation

- No steps of teaching vocabulary are used.

- This contradicts teacher views about the best way of teaching vocab. As she explained that the best way of teaching vocabulary is to put the word in a sentence and let students guess the meaning.

- This is one of the techniques taught in their teacher preparation course which is called illustrative sentences.

- However, this is a verbal technique and it was emphasized in their training that ostensive techniques come first as they are easier and more effective especially with young learners like here students.

- Thus there is a contradiction among three things (what she was taught, what she thinks is effective and what she really applies in class)

Language skills development

- No learned steps are used when teaching any of the skills.

- Views about teaching language skills showed that she believes that:

$\circ$ the best way for teaching reading is to give them time to read then read with them

$\circ$ the best way for teaching listening is to read the text for them more than one time

$\circ$ the best way for teaching writing is that students write words on board and teacher corrects for them

$\circ$ the best way for teaching speaking is to make students speak English as much as possible

- These views have very tiny relevance to what preservice teachers have been trained on in their preparation courses.

$\circ$ In reading giving students time to read is one step but other steps are neglected.

$\circ$ In listening reading the text or playing the tape is one step but other steps are neglected.

$\circ$ In writing, the views of the preservice teacher stated have nothing to do with the steps and activities taught in the preparation courses.

$\circ$ The same for speaking she only gave a general statement about what they should do.

- Again there is a contradiction among three things (what the preservice teacher was taught, what she thinks is effective and what she really applies in class)

Use of Teaching aids

- Observation: none was used in teaching.

- Views: some are important but we cannot use all because students laugh at some aids and there is no class time for aids.

- Views are based on assumptions not experience and trail as the teacher has not tried using any aids at all.

- Training: aids save class time not waste it. Aids attract and motivate students not make them laugh at the teacher

Use of Arabic

- Observation : a lot of Arabic

- Views: use it sometimes because students do not understand English but not all the time

- Training: use Arabic when it is very necessary such as teaching abstract words and difficult situations. English should be the dominant language in class

Involvement of students

- Observation: low

- Views: important

- Training: the core (involve me I'll learn)

Other aspects observed:

- Lack of enthusiasm

- Classroom management problems

Why not apply what have been learnt:

The preservice teacher stated that she can't do all the things she has learned at college because students can't change the way they use with their previous teachers and they feel that new methods are strange. She added that class time is short.

Those two reasons were not mentioned in any previous study as reasons of the theory-practice gap. Thus, they need more investigation.

It seems that the teacher surrenders to students wishes. This could be because the teacher does not want any hard times with students. She chose the easy way. May be preservice teachers need training in how to change and face change resistance. As for the issue of insufficient class time, it may be due to the preservice teacher's lack of experience or misconception that new methods of teaching take more time. Teacher educators need to take care of those two issues when designing preparation programs. 


\section{Preservice English teacher 2:}

Vocab. Presentation

- Teacher asks "What is the meaning of ....?" students provide Arabic meaning of the word and if they don't know teacher provides the Arabic translation

- No steps of teaching vocabulary are used.

- This contradicts teacher views about the best of way of teaching vocab. As she explained that the best way of teaching vocabulary is to use ostensive techniques such as visual cards, pictures, board drawings

- This is one of the techniques taught in their teacher preparation course

- This agrees with what was taught as it was emphasized in their training that ostensive techniques come first as they are easier and more effective especially with young learners like here students.

- Here there is consensus between what is taught and the views but they are different form real teaching behaviors

Language skills development

- One or no steps are used when teaching the skills

- Views about teaching language skills showed that the preservice teacher believes that:

$\circ$ the best way to teaching reading is to make students read silently.

$\circ$ the best way to teaching listening is to use the cassette player.

$\circ$ the best way to teaching writing is that students write words on board and teacher corrects for them.

$\circ$ as for teaching speaking she had no clear views about it

- These views have very tiny relevance to what they have been trained on in their courses:

- In reading, silent reading is one step but other steps are neglected and even when students began reading silently, the teacher complained that they are making noise. Making noise is normal as some students are used to loud reading; articulating sounds while reading.

$\circ$ In listening, playing the tape is one step but other steps are neglected

- In writing, the preservice teacher's views have nothing to do with the steps and activities taught in the course.

- Speaking was neglected complete by the teacher as she mentioned nothing about her views about it and she had no clue about how to teach it.

- Again there is a contradiction among three things (what she was taught, what she thinks is effective and what she really applies in class)

Use of Teaching aids

- Non used in teaching

- Views: very important to be used in class to make students understand

- Training : agrees with the views

- Training and views agree while they both contradict what was applied in class

Use of Arabic

- Observation : a lot of Arabic especially in classroom language.

- Views: Arabic is important to convey information as students can't understand English

- Training: use Arabic only when it is necessary such as teaching abstract words and difficult situations. English should be the dominant language in class.

Involvement of students

- Observation: low

- Views: important

- Training : the core (involve me I'll learn)

Other aspects observed:

- Lack of enthusiasm

- Classroom management problems.

Why not apply what have been learnt:

The preservice teacher stated that she cannot do all the things she learned in here preparation courses because the level of students is not suitable. She added that students want teachers to talk in Arabic all the time as they can't understand English. She added that, the time of class is short and not enough to apply new methods in teaching. She also mentioned that the school is not equipped well with things we learn at college.

Insufficient class time appeared again similar to the first preservice teacher. It recurrence indicates that preservice teachers needs more training in classroom management and time management. This could help provide them with more time and give them confidence in applying new methods of teaching. Two more reasons appeared here: students' low level and lack of equipments. Students' low level was not mentioned as one of the reasons of theory-practice gap in previous studies while lack of equipment was mentioned in some studies such as the study of Nunan (2003).

Preservice English teacher 3:

Vocab. Presentation

- Arabic translation is the main technique used

- No steps of teaching vocabulary are used. 
- This contradicts teacher views about the best of way of teaching vocab. As she explained that the best way of teaching vocabulary is to use pictures and illustrative sentences

- These are two techniques emphasized in the preparation course.

- This agrees with what was taught in the preparation courses.

- Here there is consensus between that is taught and the views but they are different form real teaching behaviors.

Language skills development

- No steps are used when teaching any of the skills

- Views about teaching language skills showed that the preservice teacher believes that:

$\circ$ The best way to teaching reading is that teacher reads loudly to students.

$\circ$ The best way to teaching listening is that students listen to teachers a lot.

○ The best way to teaching writing was completely neglected and no views were mentioned about it.

$\circ$ The best way to teaching speaking is to make students read and speak imitating teachers' pronunciation.

- These views have nothing to do with what they have been trained on in their preparation courses:

$\circ$ In reading students should read not the teacher.

O In listening, listen to the teacher is not a technique of activity taught in the course and even if they listen, the teacher speaks Arabic most of the time so they are listening to Arabic not English.

$\circ$ Writing was neglected as if the teacher has no information about it.

- Speaking was confused with reading and imitation was the only technique the teacher believed in.

- Again there is a contradiction among three things (what preservice teacher was taught, what she thinks is effective and what she really applies in class)

Use of Teaching aids

- Observation: None used in teaching

- Views: it is important to bring anything related to the lesson

- Training : agrees with the views

- Training and views agree while they both contradict what was applied in class

Use of Arabic

- Observation : too much Arabic

- Views: we should speak English as we are teachers of English but students make us use Arabic.

- Training: use Arabic only when it is necessary such as teaching abstract words and difficult situations. English should be the dominant language in class

- Views agree with what preservice teachers learned but teaching behaviors contradicts it.

Involvement of students

- Observation :average

- Views: important

- Training : the core (involve me I'll learn)

Other aspects observed:

- Problems in managing the class.

- Good reinforcement

Why not apply what have been learnt:

The preservice teacher stated that she loves teaching but in the traditional way. She admitted that she should change herself and added that the problem is in the teacher, students and college training. She concluded that the educational system should change in both schools and colleges.

The idea that the teacher herself prefers the traditional method of teaching, depending on translation, raises the issue of convincing preservice teachers with the avail of new methods of teaching not just introducing these methods to them. This means teacher educators need to exert more effort in explaining the rationale of each teaching method presented to preservice teachers in their preparation courses. The idea that preservice training is one of the causes of the theorypractice gap is similar to what Cheng et al (2010) has stated.

To sum up, preservice teachers presented a variety of causes of the theory-practice gap in teaching English as a foreign language. This means that teacher educators need to analyze these reasons and do significant development of English teachers' preparation courses in relation to these factors.

\section{CONCLUSION AND RECOMMENDATIONS}

The study revealed that there is a big gap among what preservice English teachers learn in their preparation courses, what they view as effective teaching and their real teaching behaviors. This was very clear in nearly all aspects of teaching (vocabulary presentation, skills development, students' involvement, and use of native language in EFL classes). Sometimes there was agreement between what preservice teachers view as effective teaching and what they had learned in their preparation courses. This indicates that some of them were convinced theoretically with what they learn in their preparation courses. However, when it came to real teaching they forgot about that and surrendered to the traditional methods of teaching. Even in the few situations they applied what they had learned in preparation courses, they applied it partially not thoroughly. Preservice English teachers gave a lot of reasons why they did not apply what 
they have learned theoretically in their real teaching. These reasons included insufficient preservice training, low level of students, students' unwillingness to change their learning behaviors and their pressure on teachers to conform to the traditional techniques of teaching, lack of sufficient time, lack of equipment and sometimes the teacher himself/herself preferred the easy way of teaching using the native language all the time not bothering about the methods and techniques of teaching.

Theoretically, this study filled a research gap. Most of the studies that dealt with theory-practice gap focused on finding out the reasons for the gap through surveys and questionnaires while the present study provides detailed insight in preservice English teachers' views about effective teaching of English and their real teaching behaviors in all major aspects of teaching. Moreover, the researcher could not find any study in Egypt related to the theory-practice gap in teaching English. Consequently, the study provides an insight to this issue in a new context.

Practically, this study provides educational authorities, teachers and teacher educators with detailed insight in preservice English teachers' views about effective teaching and their real teaching behaviors. The study recommends that early collaboration between teacher educators and schools together with incorporation of senior teachers in teacher preparation programs could help breach the theory-practice gap. The study also recommends that teacher educators should analyze the given causes of the theory-practice gap and develop the English teachers' preparation courses in accordance.

\section{SUGGESTIONS FOR FURTHER RESEARCH}

- Investigating English teacher educators' perceptions of the theory-practice gap in teaching English.

- Investigating in-service teachers' perceptions of the theory-practice gap in teaching English.

- A longitudinal study of the theory-practice gap in relation to teacher development through the accumulating years of experience.

- Experimental studies for investigating possible solutions to the theory-practice gap in teaching English.

\section{Appendix (1). Observation Sheet of Preservice English Teachers' Teaching Behaviors (Prepared by the} RESEARCHER)

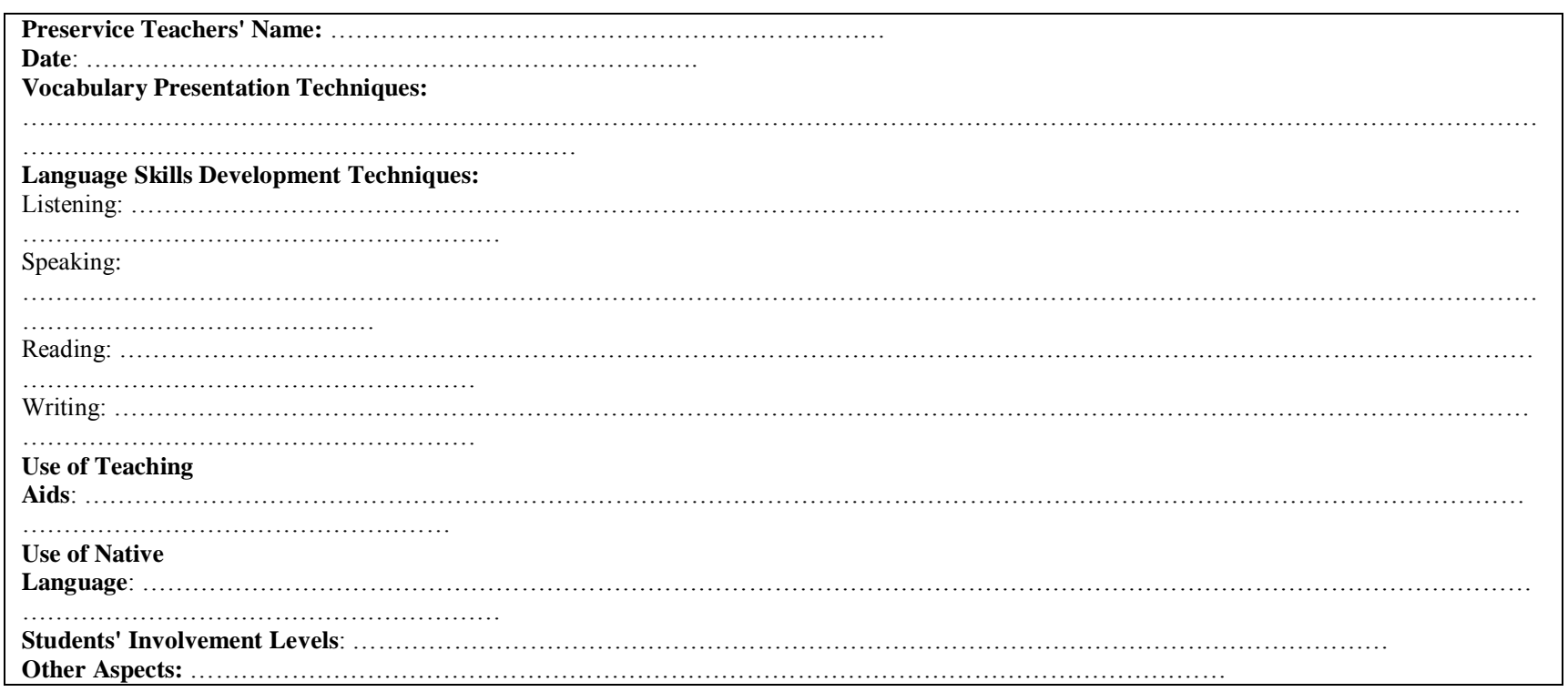

\section{APPENDIX (2). INTERVIEW QUESTIONS}

The interviewees were asked the following questions:

1- What are the effective techniques for presenting vocabulary?

2- What are the effective techniques for developing students' listening skills?

3- What are the effective techniques for developing students' speaking skills?

4- What are the effective techniques for developing students' reading skills?

5- What are the effective techniques for developing students' writing skills?

6- What do you think of the use of the native language in EFL classes?

7- What do you think of the use of teaching aids in EFL classes?

8- What do you think of students' involvement during class time?

9- Would you like to add anything? 


\section{REFERENCES}

[1] Buthelezi, T. (2004). The HIV/AIDS epidemic and teacher development: Defining positional perspectives. In R. Balfour, C. Mitchell, \& T. Buthelezi (eds.), Teacher development at the centre of change. Durban, South Africa: SEMI, 93-105.

[2] Carless, D. R. (1998). A case study of curriculum innovation in Hong Kong. System, 26, 353-368.

[3] Carless, D. R. (2001). A case study of curriculum innovation in Hong Kong. In D. R. Hall, \& A. Hewings (eds.), Innovation in English language teaching. London: Routledge, 263-274.

[4] Carless, D. R. (2003). Factors in the implementation of taskbased teaching in primary schools. System, 31(4), 485-500.

[5] Cheng, M.; Cheng, A.; \& Tang, S. (2010). Closing the gap between the theory and practice of teaching: Implications for teacher education programmes in Hong Kong. Journal of Education for Teaching, 36 (1), 91-104.

[6] Cope, P. \& Stephen, C. (2001). A role for practising teachers in initial teacher education, Teaching and Teacher Education, 17, 913-924.

[7] Dooly, M. \& Sadler, R. (2013). Filling in the gaps: Linking theory and practice through telecollaboration in teacher education, The Journal of EUROCALL, 25 (1), 4-29.

[8] D'Souza, L. (2014). Bridging the gap for beginning teachers: Researcher as mentor. International Journal of Mentoring and Coaching in Education, 3 (2), 171-187.

[9] Edge, J. \& Mann, S. (2013). Innovations in pre-service education and training for English language teachers. British Council, London, UK.

[10] Fayyaz, S. \& Omar, H. (2014). A study of contextual situatedness of English language teachers'beliefs and practices about the form-focused instruction: A case study in Sandakan district, Sabah, Procedia - Social and Behavioral Sciences, 134, 201 - 212.

[11] Hatasa, Y. (2013). The gap between theory and practice: Problems and possibilities. Journal CAJLE, 14, (1), 1-17.

[12] $\mathrm{Hu}, \mathrm{G}$. (2002). Potential cultural resistance to pedagogical imports: The case of communicative language teaching in China. Language Culture and Curriculum, 15(2), 93-105.

[13] Kareva, V. (2013). Improving quality in English language teacher education, Procedia - Social and Behavioral Sciences $70,1482-1486$

[14] Kırkgo" z, Y. (2006). Teaching English as a Foreign Language at the primary level in Turkey: An exploratory school-based case study. In M. McCloskey, M. Dolitsky, \& J. Orr (eds.), Teaching English as a foreign language in primary school. Alexandria, VA: TESOL Publications, 85-99.

[15] Kırkgo“" z, Y. (2007). Language planning and implementation in Turkish primary schools. Current Issues in Language Planning, $8(2), 174-191$.

[16] Kirkgoz,Y. (2008). A case study of teachers' implementation of curriculum innovation in English language teaching in Turkish primary education, Teaching and Teacher Education, 24, 1859-1875.

[17] $\mathrm{Li}$, D. (1998). "It is always more difficult than you plan and imagine". Teachers' perceived difficulties in introducing the communicative approach in South Korea. TESOL Quarterly, 32, 677-697.

[18] Mukeredzi,T. \& Mandrona, A. (2013). The journey to becoming professionals: Student teachers' experiences of teaching practice in a rural South African context, International Journal of Educational Research, 62, 141-151.

[19] Nunan, D. (2003). The impact of English as a global language on educational policies and practices in the Asia-Pacific region. TESOL Quarterly, 37(4), 589-613.

[20] Özdemir, S.; Ceylan, M. \& Canoğlu, S. (2015). To What extent can pre-service teachers turn theoretical knowledge they have acquired into practice? International Online Journal of Educational Sciences, 7 (2), 265 - 282.

[21] Peercy, M. (2012). Problematizing the theory-practice gap: How ESL teachers make sense of their preservice education, Journal of Theory and Practice in Education Eğitimde Kuram ve Uygulama, 8 (1), 20-40.

[22] Ping, W. (2015). An Evaluation of the preservice English teacher education in a university in China: Pros and cons from an insider's journey of learning. JoP 6 (1): $151-174$.

[23] Safari, P. \& Rashidi, N. (2015). Teacher education beyond transmission: Challenges and opportunities for Iranian teachers of English, Issues in Educational Research, 25(2), 187-203.

[24] Samuel, M. (1998). Changing lives in changing times: Pre-service teacher education in post-apartheid South Arica. TESOL Quarterly, 32(3), 576-584.

[25] Tudor, I. (2003). Learning to live with complexity: Towards an ecological perspective on language teaching, System, 31(1), 1-12.

[26] Fayyaz, S. \& Omar, H. (2014). A study of contextual situatedness of English language teachers' beliefs and practices about the form-focused instruction: A case study in Sandakan district, Sabah, Procedia - Social and Behavioral Sciences, 134, $201-212$.

Hosam ELDeen A. El-Sawy, Master in TESOL, Alexandria University, Egypt, 2005. PhD in TESOL, Alexandria University, Egypt, 2010.

He worked as a Teaching Assistant, an Assistant Lecturer and a Lecturer at the Faculty of Education, Damnahour University, Egypt. He worked as an assistant professor at Jouf University, KSA. He has published work in using social network sites in teaching English, using picture storybooks in teaching EFL reading skills, authentic tasks for improving EFL speaking skills and flipping EFL university classes. Authenticity in language teaching and using technology in language teaching are his current research interests. 